\title{
BIOCHEMICAL STUDIES ON PRESSURE-SORE HEALING IN PARAPLEGICS ${ }^{\star}$
}

\author{
By S. R. Kermani, M.B.B.S., D.Rehab., Mahmooda Siddiqui, M.Sc., \\ SAEEDA ZaIN, M.Sc. and Z. K. KaZI, F.R.C.S. \\ Department of Surgery and Orthopaedics, Finnah Postgraduate \\ Medical Centre, Karachi, Pakistan
}

HEALING of bed sores in paraplegics is known to be a delayed process. Very little work has been done on human subjects while several studies have been reported on wound healing in experimental animals. These include such studies as delayed effect of denervation on the healing of superficial skin defect (Muren \& Zederfeldt, I966), effect of chronic anaemia on wound tensile strength (Bain et al., I 966), effect of infection on wound healing (Smith \& Enquist, I967), and enzymatic studies during early period of wound healing (Raekallio \& Makinen, 1967). The present study differs in that it was planned to investigate some biochemical aspects of delayed wound healing in paraplegic patients.

Material and Methods. Nine paraplegics between 20 and 50 years of age, with pressure sores, were selected at random. The plasma and granulation tissue were studied to assess the protein contents. Because of the low protein content in the tissues of these patients another five paraplegics between 25 and 45 years with similar bed sores were added for further biochemical studies. These included estimation of haemoglobin, plasma proteins (albumin and globulin), and the analysis of granulation tissue from the sores for protein, water content, free amino acids, nucleic acids, glycogen and hexosamines. On the tenth, twentieth, thirtieth and fiftieth day, after excision of slough, samples of blood and granulation tissue were taken for analysis. Due to lack of availability of any other group with similar granulating wounds, control studies were not possible. Investigations for urinary tract infection were also performed during the same study period. These consisted of examination for urinary protein, cell count, culture, estimation of blood urea and intravenous pyelogram.

With regard to the management a routine of two-hourly change of posture was observed. Appropriate antibiotics, anabolic steroids and fresh blood transfusions were given when indicated. They were provided with a normal hospital diet of 2700 Cals. with additional proteins in the form of eggs, milk and predigested food yielding about 300 Cals. Wounds were closed by direct suture, rotation of flaps, or by free-skin grafts depending upon individual case. The wounds of two patients healed in three months, one in nine months and one in one year. One patient died.

Chemical Methods. I. Total plasma proteins, albumin and globulin were determined by the Biuret method.

* This study was supported by a grant VRA-PAK-IO-66 from the Department of Health, Education and Welfare, U.S.A. 
2. Haemoglobin by the Cyanmethaemoglobin method.

3. Granulation tissue: a piece of tissue (about $700 \mathrm{mg}$.) was taken and chilled at $-4^{\circ} \mathrm{C}$. About $100-150 \mathrm{mg}$. of the tissue was immediately digested in 30 per cent. $\mathrm{KOH}$ for glycogen estimation by the method described by Montgomery (1957) and the water content of the tissue was determined by drying a piece of tissue (about $150 \mathrm{mg}$.) at $110^{\circ} \mathrm{C}$. for 10 hours. A Io per cent. homogenate was prepared in cold distilled water and appropriate aliquots were taken for the analysis of proteins, DNA and RNA. Proteins were estimated by the method of Lowry (Lowry et al., 195I). Nucleic acids were determined by Schmidt and Thannhauser (1945) procedure. Free amino acid content was determined by Rosen's (1957) method on a tissue homogenate in methanol. For hexosamine determination I00-1 $50 \mathrm{mg}$. of tissue was hydrolysed with $3 \mathrm{~N}$. $\mathrm{HCl}$ at $106^{\circ} \mathrm{C}$. for Io hours and neutralised and then estimated by the Cessi and Piliego method.

\section{RESULTS AND DISCUSSION}

Plasma Protein. Total plasma protein levels observed in all the paraplegics were lower than the normal values (Table I). Subsequently it was found that plasma protein levels were higher in the patients with healing ulcers as compared with those showing delayed healing (Table II). Guttmann (I945, I953), Robinson (1954) and Edwards et al. (1967) have shown that in traumatic paraplegics without pressure sores, plasma protein levels decrease with inversion of albumin/globulin ratio. Low plasma protein level in our patients may also be due to protein loss from the ulcers.

The albumin/globulin ratio was altered in all the patients, significantly in the late healers (Table II). Chanutin \& Gjessing (1946-47) have shown in experimental wound healing that the albumin decreases considerably with alteration in globulin fractions in the early period, and values return to normal by I0-I 5 days. But the albumin/globulin ratio in our patients did not return to normal even after 50 days. This was probably due to continuous loss of proteins from the open wounds. Apparently the increased protein intake was not sufficient to maintain normal plasma protein level.

Haemoglobin. The haemoglobin levels were initially low in all, but lower in the late-healing patients (Table II). James et al. (1954) have shown that until the twenty-fifth day after injury (particularly in patients with burns), not only is the haemoglobin synthesis decreased, but there is an enhanced destruction of haemoglobin. If the bed sores are considered similar to burns the decrease in haemoglobin can be explained. Moreover, the values subsequently returned to normal in early healers.

Granulation Tissue. Protein. The average protein content of the granulation tissue was lower in late healers (Tables III and IV). When granulation tissue was further analysed it was found that initially, protein content was high in all the patients and was even higher in the early healers. The values gradually came down as the healing progressed in both the early- and late-healing cases. Similar observations have also been made by Bollet et al. (1958), who noticed that protein contents remain constantly high until the third week and then decrease. The initial increase of tissue protein is characteristic of immature regenerating tissue, as the tissue matures its protein content decreases. The water content in this 
TABLE I

Plasma Proteins and Tissue Proteins of Nine Randomised Paraplegics with Bed Sores

$\begin{array}{cc}\underset{(\mathrm{g} \%)}{\text { Plasma proteins }} & \begin{array}{c}\text { Granulation tissue } \\ (\mathrm{g} \%)\end{array} \\ 6.43 \pm 0.3 & \mathrm{II} \cdot 39 \pm 0.57\end{array}$

Mean values with standard error.

\section{TABLE II}

Plasma Protein, Albumin, Globulin and Haemoglobin of Patients with Early and Delayed Healing Wounds

\begin{tabular}{|c|c|c|c|c|c|c|c|c|}
\hline \multirow[b]{2}{*}{ Days } & \multicolumn{2}{|c|}{$\begin{array}{c}\text { Total plasma } \\
\text { protein } \\
(\mathrm{g} \%)\end{array}$} & \multicolumn{2}{|c|}{$\underset{(\mathrm{g} \%)}{\text { Albumin }}$} & \multicolumn{2}{|c|}{$\begin{array}{l}\text { Globulin } \\
(\mathrm{g} \%)\end{array}$} & \multicolumn{2}{|c|}{$\begin{array}{c}\text { Blood } \\
\text { haemoglobin } \\
(\mathrm{g} \%)\end{array}$} \\
\hline & $\begin{array}{c}\text { Early } \\
\text { healing }\end{array}$ & $\begin{array}{l}\text { Delayed } \\
\text { healing }\end{array}$ & $\begin{array}{c}\text { Early } \\
\text { healing }\end{array}$ & $\begin{array}{l}\text { Delayed } \\
\text { healing }\end{array}$ & $\begin{array}{c}\text { Early } \\
\text { healing }\end{array}$ & $\begin{array}{l}\text { Delayed } \\
\text { healing }\end{array}$ & $\begin{array}{c}\text { Early } \\
\text { healing }\end{array}$ & $\begin{array}{l}\text { Delayed } \\
\text { healing }\end{array}$ \\
\hline IO & $6 \cdot 8$ & $5 \cdot 9$ & $3 \cdot 6$ & $I \cdot 4$ & $3 \cdot 2$ & $4 \cdot 5$ & 10.9 & 9.5 \\
\hline 20 & $7 \cdot 3$ & $6 \cdot 5$ & $3 \cdot 7$ & $2 \cdot 4$ & $3 \cdot 6$ & $4 \cdot I$ & $12 \cdot 6$ & $10 \cdot 08$ \\
\hline 30 & $7 \cdot 15$ & $5 \cdot 7$ & $3 \cdot 7$ & $\mathrm{I} \cdot 7$ & 3.45 & $4 \cdot 0$ & I3.75 & $9 \cdot 2$ \\
\hline 50 & $7 \cdot 7$ & $5 \cdot 7$ & $4 \cdot 0$ & $2 \cdot 0$ & $3 \cdot 7$ & $3 \cdot 7$ & I 4.4 & II 0 \\
\hline
\end{tabular}

Mean values.

tissue was also high in the initial stages of healing. It gradually decreased as tissue matured.

Free Amino Acid. Free amino acid pool was higher in the early-healing patients than in the late-healing ones (Tables III and IV), which is in agreement with the findings of Williamson and Fromm (1955), who showed that sulphurcontaining amino acids accumulate early in the regenerative tissue for protein synthesis and decrease as tissue synthesis proceeds. Free amino acid level was directly proportional to plasma protein level in all the patients. It appears that low free amino acid level, together with low plasma proteins, reflects protein deficiency and possibly poor protein synthesis in the tissues, which accounts for delayed healing.

$D N A$ and $R N A$. DNA and RNA were initially high in the tissues of all patients but decreased with time (Tables III and IV). Initial increase in DNA and RNA was also reported by Woessner and Boucek (196I) and Lampiaho and Kulonen (1967). This increase in the nucleic acids content reflects cellular proliferation. Subsequent decrease may be proportional to maturation of tissue and decrease of cellular content. 


\section{TABLE III}

Protein, Free Amino Acid, DNA, RNA, Glycogen, Hexosamines and Water Content in the Granulation Tissue of Two Patients with Early Healing Sores on Different Days of Study. Results are Expressed in Terms of Wet Weight

\begin{tabular}{|c|c|c|c|c|c|c|c|}
\hline Days & $\begin{array}{l}\text { Protein } \\
(\mathrm{g} \%)\end{array}$ & $\begin{array}{l}\text { Free amino } \\
\text { acid } \\
\text { (millimole/ } \\
\text { I00 g.) }\end{array}$ & $\begin{array}{l}\text { DNA } \\
(\mathrm{g} \%)\end{array}$ & $\begin{array}{l}\text { RNA } \\
(\mathrm{g} \%)\end{array}$ & $\begin{array}{l}\text { Glycogen } \\
\text { (g. } \%)\end{array}$ & $\begin{array}{l}\text { Hexosamines } \\
(\text { g. } \%)\end{array}$ & $\begin{array}{c}\text { Water } \\
\text { content } \\
(\mathrm{g} . \%)\end{array}$ \\
\hline $\begin{array}{l}10 \\
20 \\
30 \\
50\end{array}$ & $\begin{array}{l}\text { IO.5 } \\
\text { II } .05 \\
8.67 \\
8.4\end{array}$ & $\begin{array}{l}2 \cdot 9 \\
3 \cdot 37 \\
2 \cdot 87 \\
3 \cdot 05\end{array}$ & $\begin{array}{l}0.45 \\
0.417 \\
0.406 \\
0.406\end{array}$ & $\begin{array}{l}0.46 \\
0.435 \\
0.44 \\
0.425\end{array}$ & $\begin{array}{l}I \cdot I 85 \\
I \cdot I 5 \\
I \cdot I 8 \\
I \cdot O I 5\end{array}$ & $\begin{array}{l}0.2 \mathrm{I} 6 \\
\mathrm{I} \cdot \mathrm{I} 95 \\
0.8 \mathrm{I} 4 \\
0 . \mathrm{I} 8\end{array}$ & $\begin{array}{l}85 \cdot 8 \\
83 \cdot 6 \\
83 \cdot 01 \\
80\end{array}$ \\
\hline
\end{tabular}

Mean values.

\section{TABLE IV}

Protein, Free Amino Acid, DNA, RNA, Glycogen, Hexosamines and Water Content in the Granulation Tissue of Three Patients with Late Healing Sores on Different Days of Study. Results are Expressed in Term of Wet Weight

\begin{tabular}{|c|c|c|c|c|c|c|c|}
\hline Days & $\begin{array}{l}\text { Proteins } \\
\text { (g. \%) }\end{array}$ & $\begin{array}{l}\text { Free amino } \\
\text { acid } \\
\text { (millimole/ } \\
\text { Io0 g.) }\end{array}$ & $\begin{array}{l}\text { DNA } \\
(\text { g. } \%)\end{array}$ & $\begin{array}{l}\text { RNA } \\
(\text { g. } \%)\end{array}$ & $\begin{array}{l}\text { Glycogen } \\
\text { (g. \%) }\end{array}$ & $\begin{array}{l}\text { Hexosamines } \\
\text { (g. \%) }\end{array}$ & $\begin{array}{c}\text { Water } \\
\text { content } \\
(\mathrm{g} . \%)\end{array}$ \\
\hline IO & 9.05 & $\mathrm{I} \cdot \mathrm{I} 4$ & 0.298 & 0.332 & 0.403 & 0.296 & $87 \cdot 83$ \\
\hline 20 & $8 \cdot 3$ & $\mathrm{I} \cdot 07$ & 0.265 & 0.225 & 0.269 & 0.305 & 86 \\
\hline 30 & $7 \cdot 3$ & 0.9 & $0.23 I$ & $0.21 \mathrm{I}$ & 0.278 & 0.230 & $83 \cdot 3$ \\
\hline 50 & $7 \cdot 0$ & 0.98 & 0.204 & $0 \cdot 196$ & 0.235 & 0.21 & $84 \cdot 6$ \\
\hline
\end{tabular}

Mean values.

Glycogen. The glycogen content was also initially higher in the early-healing cases in comparison to the late healers but later there was a gradual decrease in both (Tables III and IV). It is suggested that active granulation tissue of early healers stores more glycogen than the granulation tissue of late healers.

Hexosamines. Bound hexosamines indicate the amount of the mucopolysaccharides present in the tissue. The hexosamines thus estimated were found to be decreased in the granulation tissue of early-healing patients but comparatively raised in late healers (Tables III and IV). Dunphy and Udupa (I955) have shown that in normal wound healing mucopolysaccharides after an initial increase, in two to six days begin to fall rapidly as collagen synthesis increases. They also found that their concentration in vitamin $\mathrm{C}$ or protein deficiency states rises progressively by the twelfth to fourteenth day which is far in excess of that seen at the peak 
observed in normal wounds, about the fifth day. The lower level of hexosamines in the early-healing tissue therefore, suggests its utilisation during collagen synthesis whereas high values in late-healing patient suggest slow utilisation due to protein deficiency.

None of these patients had significant urinary tract infection. Two patient's urine showed traces of protein, one in early healing and the other in delayed healing group. The cell count never exceeded Io/c.mm. in any patient. Culture on repeated random urine samples showed growth of organisms (coliform, proteus and staphylococci) in four cases. Contamination of the samples cannot be ruled out as the organisms varied in different samples from the same patient. Blood urea levels were never more than $45 \mathrm{mg}$. $/ 100 \mathrm{ml}$. Intravenous pyelograms performed at the completion of study were normal in all the patients. Only one patient had manifest clinical symptoms which responded to a course of Nitrofurantoin. We believe that this mild infection has not affected the wound healing.

\section{CONCLUSION}

It was noticed that, following injury, haemoglobin and plasma proteins are initially decreased. Albumin/globulin ratio also alters but the values return to normal as healing progresses. It was further found that there was an initial increase in proteins, free amino acids, water and nucleic acid contents of the granulation tissue in these patients but with the progress in collagen synthesis the values decreased. The values were higher in the early-healing patients. Latehealing patients were deficient in protein but despite the deficiency there was evidence of early reparative activity. Higher values of hexosamines in the latehealing patients are probably due to a prolonged productive phase, due in turn to a protein deficiency state. An initial high glycogen content also appears to be a characteristic of active granulation tissue.

We.found that deficiency of protein played a major role in delayed healing. Even the dietary intake of protein could not make up for the loss through the wound exudate. Adequate replen ihment of protein could have saved the patients from deterioration.

\section{SUMMARY}

A biochemical study was made on I4 paraplegics to evaluate the possible causes of delayed healing of bed sores. In five of these, more detailed investigations on the plasma and granulation tissue were undertaken. They included estimation of haemoglobin, plasma proteins, albumin/globulin ratio and analysis of granulation tissue for proteins, water content, nucleic acids, free amino acids, glycogen and hexosamines at various stages of healing. Findings from this study have been compared with those of other workers. Deficiency of proteins appears to be the main factor responsible for delayed wound healing.

\section{RÉSUMÉ}

Une étude biochimique a été effectuée sur I4 paraplégiques pour essayer de rechercher les causes possibles du retard de cicatrisation des escarres.

Parmi cinq de ceux-ci, des recherches plus détaillées sur le plasma et le tissu de granulation one été effectuées. Elles ont porté sur l'estimation de l'hémoglobine et de l'analyse du 
tissu de granulation, sur les protéïnes, la teneur en eau, les acides nucléiques, les aminosacides libres, le glycogène et les hexo-amines, à différents stades de la cicatrisation.

Les résultats de cette étude ont été comparés à ceux d'autres auteurs. La diminution des protéïnes apparaît comme étant le principal facteur responsable de la lenteur de cicatrisation.

\section{ZUSAMMENFASSUNG}

Eine biochemische Studie wurde an I4 Paraplegikern ausgeführt, um die möglichen Ursachen einer verzögerten Heilung von Druckgeschwüren zu finden. In 5 dieser Fälle wurden detaillierte Untersuchungen von Plasma und Granulationsgewebe ausgeführt. Diese betrafen Bestimmung von Haemoglobin, Plasma-Proteine, Albumin/Globulin Ratio und Analyse des Granulationsgewebe auf Protein, Wassergehalt, nukleide Säuren, freie Amino Azididät, Glykogen und Hexosamine in verschiedenen Stadien der Heilung. Die erhobenen Befunde wurden mit denen anderer Antoren verglichen. Defizienz von Protein scheint der verantwortliche Hauptfaktor für die verzögerte Wundheilung zu sein.

Our thanks are due to Professor A. Rehman, Ph.D., Head of the Department of Biochemistry, Jinnah Postgraduate Medical Centre, Karachi, and to Dr. Zainul Abedin, Ph.D., Head of the Department of Biochemistry, University of Karachi, for their help and guidance.

\section{REFERENCES}

Bain, J. W., Crawford, D. T. \& Ketcham, A. S. (1966). Annals of Surgery, 164, 243. Bollet, A. J., Goodwin, J. F. \& Simoson, F. W. (1958). Proceedings of the Society for Experimental Biology and Medicine, 99, $4 \mathrm{I} 8$.

Cessi, C. \& Piliego, F. (I960). Biochemical fournal, 77, 508.

Chanutin, A. \& GJessing, E. C. (1946). Fournal of Biological Chemistry, 165, 42 I.

Dunphy, J. E. \& Udupa, K. N. (1955). New England fournal of Medicine, 253, 847.

Edwards, K. B., Frankel, H. \& Guttmann, L. (1967). Paraplegia, 5, 49.

Gjessing, E. C. \& Chanutin, A., (1947). Fournal of Biological Chemistry, 169, 657.

Guttmann, L. (1945). Medical Times, New York, 73, 318.

Guttmann, L. (1953). In Medical History of the Second World War, Surgery, ed. Cope, Z., 422. London: H.M. Stationery Office.

James, G. W., Aвbott, L. D., Brooks, B. W. \& Evans, E. I. (1954). Fournal of Clinical Investigation, 33, 150.

LAMPIAHO, K. \& KULONEN, E. (1967). Biochemical fournal, 105, 333.

Lowry, O. H., Rosebrough, N. J., Farr., A. L. \& RANDall, R. J. (I95I). Fournal of Biological Chemistry, 193, 265.

MONTGOMERY, R. (1957). Archives of Biochemistry and Biophysics, 67, 378.

MuREN, A. \& ZEDERFELDT, B. (I966). Acta chirurgica scandinavica, 132, 6 I8.

RaEkallio, J. \& Makinen, P. L. (1967). Nature, London, 213, I037.

Robinson, R. (1954). Proceedings of the Royal Society of Medicine, 47, I 109.

Rosen, H. (1957). Archives of Biochemistry and Biophysics, 67, Io.

Schmidt, G. \& Thannhauser, S. J. (I945). Fournal of Biological Chemistry, I6I, 83.

SMITH, M. \& ENQUist, I. F. (1967). Surgery Gynecology and Obstetrics, 125, 965.

Williamson, M. B. \& Fromm, H. J. (1955). Fournal of Biological Chemistry, 212, 705.

WOESSNER, J. F. Jr. \& BouCEK, R. J. (I96I). Archives of Biochemistry and Biophysics, 93, 85. 